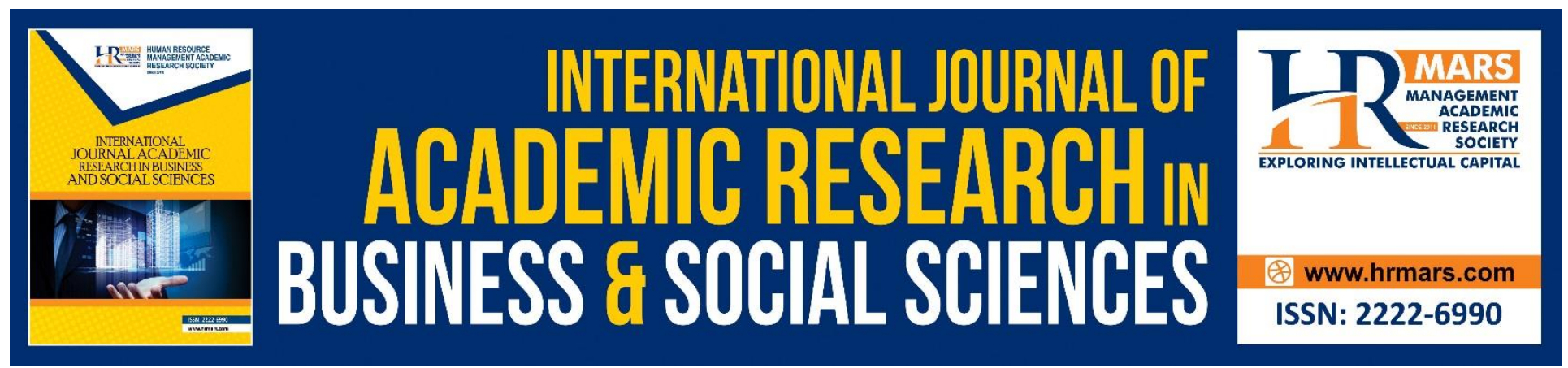

\title{
The Effect of Technology Acceptance on Student Understanding During ODL Sessions in UiTM Melaka
}

\section{Nurul Asma Mazlan, Nurhafizah Mohd Zolkapli, Nur Aqilah Norwahi, Wan} Musyirah Wan Ismail

To Link this Article: http://dx.doi.org/10.6007/IJARBSS/v10-i9/8076

DOI:10.6007/IJARBSS/v10-i9/8076

Received: 09 July 2020, Revised: 24 July 2020, Accepted: 15 August 2020

Published Online: 13 September 2020

In-Text Citation: (Mazlan, Zolkapli, Norwahi, \& Ismail, 2020)

To Cite this Article: Mazlan, N. A., Zolkapli, N. M., Norwahi, N. A., \& Ismail, W. M. W. (2020). The Effect of Technology Acceptance on Student Understanding During ODL Sessions in UiTM Melaka. International Journal of Academic Research in Business and Social Sciences. 10(9), 1166-1177.

\section{Copyright: (c) 2020 The Author(s)}

Published by Human Resource Management Academic Research Society (www.hrmars.com)

This article is published under the Creative Commons Attribution (CC BY 4.0) license. Anyone may reproduce, distribute, translate and create derivative works of this article (for both commercial and non-commercial purposes), subject to full attribution to the original publication and authors. The full terms of this license may be seen

at: http://creativecommons.org/licences/by/4.0/legalcode

\section{Vol. 10, No. 9, 2020, Pg. 1166 - 1177}

Full Terms \& Conditions of access and use can be found at http://hrmars.com/index.php/pages/detail/publication-ethics 


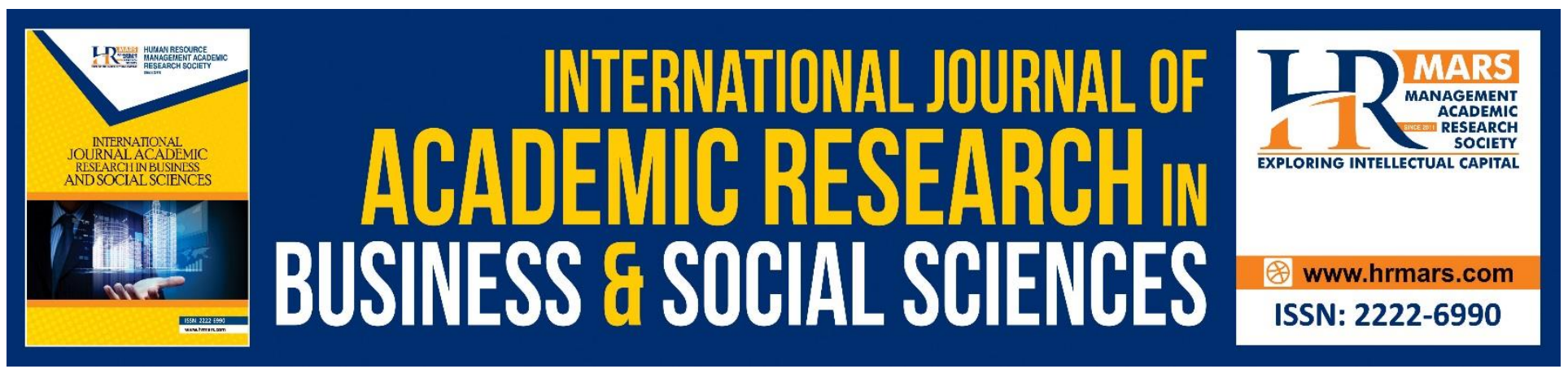

\title{
The Effect of Technology Acceptance on Student Understanding During ODL Sessions in UiTM Melaka
}

\author{
Nurul Asma Mazlan \\ Academy of Language Studies, University Teknologi MARA Melaka, Malaysia
}

Nurhafizah Mohd Zolkapli

Faculty of Business and Management, University Teknologi MARA Melaka, Malaysia

Nur Aqilah Norwahi

Academy of Language Studies, University Teknologi MARA Melaka, Malaysia

\section{Wan Musyirah Wan Ismail}

Faculty of Business and Management, University Teknologi MARA Melaka, Malaysia

\begin{abstract}
This study focuses on technology acceptance during implementation of Online Distance Learning (ODL) in UiTM Melaka during Restricted Movement Order (MRO) due to Pandemic Covid-19. It is to identify how technology acceptance could affect the student understanding. This study collected survey from 370 students from three branches in UiTM Melaka. The study is descriptive and analytical which using quantitative method using SPSS analysis in order analyze the relationship between student understanding and technology acceptance. Result shows that it can be signified that there is a positive and strong relationship existed between technology acceptance and student understanding, with the correlation of 0.613 . The $p$ value that is lower than 0.01 represented that there is significant relationship between technology acceptance and student understanding. Therefore, the results implied that technology acceptance can positively influence student understanding about the content of learning activities that have been provided by their lecturer during ODL sessions. It can be concluded that the more students accept and understand how to use the technology, the more they could understand about the content of learning during ODL sessions.
\end{abstract} Keywords: Technology Acceptance, Student Understanding, Online Distance Learning, Restricted Movement Order, Covid-19.

\section{Introduction}

The outbreak of COVID-19 in Wuhan, China, at the end of 2019, was considered as a major public health emergency because of the unusual fast rate in which the virus is spreading, the widest scope of infection, and the most difficult to prevent and control in China since its establishment (Willian \& 
INTERNATIONAL JOURNAL OF ACADEMIC RESEARCH IN BUSINESS AND SOCIAL SCIENCES Vol. 10, No. 9, 2020, E-ISSN: 2222-6990 @ 2020 HRMARS

Chew: 2020; Moritz et. al, 2020; Zhou et. al, 2019) until it spread rapidly to other countries all over the world (Andrea \& Giuseppe, 2020; Catrin et. al, 2020; Hien Lau et. al, 2020) including Malaysia (Rampal \& Seng, 2020). Affected by these pandemic outbreaks, the Malaysian government requires departments of all levels to organize forces to limit or stop crowd gathering and requires nonessential enterprises to suspend production and business operations as well as normal economic and social activities (Salim et. al, 2020). Moreover, education sector in Malaysia is also affected because of Restriction Movement Order (RMO) that has been enforced on 18 March 2020 for 14 days due to the rising number of infected COVID-19 cases (Awani, 2020). Subsequently, Malaysian Prime Minister extended the RMO period until 28 April 2020 since the infected active cases and fatality rate keep on increasing in which 4683 cases have been reported with 76 deaths in total (WHO et. al, 2020).

Due to this pandemic outbreak, it is also affecting Malaysia's education system in both schools and tertiary levels. To avoid unsafe social contact between lecturers and students that can cause situation to become more worst, all teaching and learning process and activities must be held online. Hence, Universiti Teknologi MARA (UiTM) had introduced Open and Distance Learning (ODL) for one semester initially starting from 13 April 2020 until the end of the current semester.

While Malaysia is trying to fight the COVID-19 outbreaks (Zhang et. al, 2020), the teaching and learning process still need to be continued with the method of focusing on online teaching and learning (Gorka et. al, 2020). Based on the statement made by the Minister of Science, Technology and Innovation Khairy Jamaluddin (Awani, 2020), COVID-19 directly or indirectly show the group of digital illiteracy. This issue is not only faced by Malaysian but also in all over the world. Because of this reason, it is important to spread common awareness to all educators to emphasize and focus on empathetic elements as an effort to deliver knowledge and information to the student during RMO (KPT Guidelines, 2020). Besides, there are several learning strategies that are appropriate for this situation which include mobile ubiquitous learning (u-Learning) which is a learning strategy that integrates mobile technology that enables learning to be carried out without limits (seamless), anywhere, anytime and in any way (according to the context of learning) based on the characteristics, needs/desires of students. Each learning activity consists of activities before class (online), offline/online, and activities after class (online). The principles of mobile ubiquitous learning are: (1) mobility, (2) adaptability, (3) accessibility, (4) interactivity, (5) interoperability, (6) immediacy, (7) permanency, (8) pervasiveness, and (9) context awareness (Naib Canselor UiTM: 2020).

The concept of open learning and distance education system focuses on open access to education and training to make the learners free from the constraints of time and place and offering flexible learning opportunities to individuals and groups of learners. Open and distance learning (ODL) is one of the most rapidly growing fields of education now a days and it has substantial impact on all education delivery systems (Bates, 1995; Bosch, 1997; Bradley \& Yates, 2000).

The term open and distance learning reflects both the fact that all or most of the teaching is conducted by someone who is away from the learner and that the mission aims to include greater dimensions of openness and flexibility, whether in terms of access, curriculum or other elements of structure. Open and distance learning systems can usually be described as made up of a range of components such as: the mission or goal of a particular system, programs and curricula, 
INTERNATIONAL JOURNAL OF ACADEMIC RESEARCH IN BUSINESS AND SOCIAL SCIENCES Vol. 10, No. 9, 2020, E-ISSN: 2222-6990 @ 2020 HRMARS

teaching/learning strategies and techniques, learning material and resources, communication and interaction, support and delivery systems, students, tutors, staff and other experts, management, housing and equipment, and evaluation (Saima et. al, 2012).

Nevertheless, this 'forced' online learning has its issues in its implementation. While learning still goes on, it does not take into account the learning or for that matter the teaching styles/personality that takes place in the face to face classroom. There are technological options, but they are not the same as the face to face and students with outdated technology may find it difficult to keep up. For an example, a student was to take a midterm online using respond for lecturers. After several attempts to download the browser, it was discovered that her computer was outdated and not compatible. That said, if students wanted online classes, they would have registered for them and not be in the brick and mortar buildings. Also, those with accessibility issues may find it more challenging as they may not be good with following 'written' instructions that are found in the online learning environment. Another example, lecturers posted on the course announcement page that we would not meet April 15 as planned. A student sent an email asking if we were meeting. He is registered with accessibility services again suggesting the challenges of being online (Ngampornchai \& Adams, 2016).

\section{Literature Review}

In ensuring ODL to be implemented successfully, it is crucial that both students and educators are well trained in adapting the technology into their teaching and learning process. Undeniably in the past few years, with the vast development of technologies and wide usage of the Internet, online teaching and learning has become part of the routine practices of universities all over the world (Hartnett, St. George \& Dron, 2011). Now that the whole world is facing a pandemic where movements are restricted, ODL is seen to be taking over teaching and learning process at every level in order to keep students adhere to their study plan and graduate as scheduled. In UiTM, various platforms such as Google Classroom, Edmodo, WhatsApp, Zoom and MOOCs, among others. Massive open online courses (MOOCs) was first created to assist college instruction to those who wish to study online as long as they have access to a computer with Internet connection (Kurzman, 2013).

According to Abd Rahman et. al (2020), he believes that although there are various online platforms available, WhatsApp and Telegram applications should be highlighted and recommended because of low data usage, can download picture and video as well as can download voice record of the lecturer. This opinion is aligned with the findings in a study conducted by William (2018) who indicates that about $80 \%$ students agreed to use WhatsApp and Telegram as an online learning platform because these platforms are user friendly, easy to access, suitable for the students who live in rural areas and have poor internet connection as well as it is also conformable to the teaching process that is intended to be delivered.

While these platforms are deemed to be helpful in assisting online classroom, there are still uncertainties in just how effective it really is especially for students who have poor Internet connection, outdated technology as well as knowledge in handling these online platforms. Previously, $\mathrm{ODL}$ is referred to as web-based training, e-learning, distributed learning, Internet-based learning, web-based instruction, cyber learning, virtual learning or net-based learning (Urdan \& Weggen, 
INTERNATIONAL JOURNAL OF ACADEMIC RESEARCH IN BUSINESS AND SOCIAL SCIENCES Vol. 10, No. 9, 2020, E-ISSN: 2222-6990 @ 2020 HRMARS

2000). As stated by Keengwe \& Kidd (2010), the focus of online learning is not only on the online contexts but there are numerous computer-based learning platforms and delivery methods such as multimedia, education programming, games and of course the new media on fixed and mobile platforms in various disciplines. Students are not only expected to be mentally ready for ODL within a short notice due to the pandemic but also to set up the technologies at home and learn ways to adapt to these online learning platforms. In regard to ODL, it was found that there are three categories of support which were instructional, peer and technical support. In this study, the findings suggest that educators should often communicate with their students provide an easy way of accessing the platforms (Lee, Srinivasan, Trail, Lewis \& Lopez, 2011), hence showing it is important for students to have not just instructional and peer but also technical supports.

Another study has shown that students' attitudes towards technology are highly based on the usefulness and ease of use when it comes to the technology adapted in ODL (Edmunds, Thorpe \& Conole, 2012). Just as how students have different learning styles, they also have different levels of acceptance with technology. Their demographic background also needs to be taken into account as some students come from rural areas with poor Internet connection. This is especially worrying for group assessments where students from this background will feel pressurized to be in the team with their classmates (Valentine, 2002). In addition to that, some also rely only on basic technologies such as mobile phones instead of personal computers or laptops where certain interface of the platforms is not user friendly. Access to materials plays a significant role in ODL where it has been found that students' positive perception on ODL is linked with access to resources required for their study such as computer, mobile phones and Internet and lack of this access has caused major disruption in students' learning or ability to further their study (Mittlemeier et. al., 2019). Besides, poor Internet connection and regular connections failures also contribute greater to this issue than the platforms used (Luz, Rolando, Slavador \& Souza, 2018). Thus, failure to acquire learning materials due to technological setbacks may impede students' development as well as ODL process.

Modern technologies require knowledge so as to fully utilize them efficiently. Researchers assert that ODL can be as effective as face-to face classroom (Shachar \& Newmann, 2003) as it offers flexibility and convenience in study programme (Viola, Saeki \& Hendricker, 2019). On the other hand, Balabas (2017) has reported that instructors also play an important part in assisting students in mastering electronic courses to successfully complete the course. It is also found that without the personal assistance of the lecturers, it will be challenging for students to learn complicated topics and to complete their assignments, thus, students are still not ready to work in a completely independent condition (Kireev, Zhundibayeva \& Aktanova, 2019). It is reported by Alebaikan and Troudi (2010) that in Saudi, students are so used to conventional classrooms that is a challenge for them to adapt to ODL. Moreover, since MCO is enforced within a short notice, students have no choice but to quickly adapt to ODL and it has not been a smooth stay at home. The President of the Malaysian Association of Private Colleges and Universities (MAPCU), Datuk Parmjit Singh, stated that the pedagogical demands of ODL which is very different from the conventional delivery has caused difficulties for students to adjust where instead of just raising hands and asking questions in class to get instant feedbacks from lecturers, they now have to prepare themselves by doing more background reading before ODL and participate in online discussions (Arumugam, 2020). He also added that students are concerned with the efficiency and reliability of online tests too. 
Universities around the world have started integrated blended learning way back in the 2000s. With the strike of COVID-19 pandemic in late February 2020, Malaysian Government has decided to enforce MCO where every sector including education is instructed to be closed and both educators and students are required to incorporate ODL, taking over the usual face-to-face classrooms. Although blended learning is quite common, full force ODL is still relatively new in Malaysia in both public and private learning institutions. In this era of globalisation, one cannot deny the significance of online learning but the knowledge in using the hardware, software and the Internet is also the primary requirement in ODL (Ventayen, Salcedo \& Orlanda-Ventayen, 2020). Hence, investigating the stakeholders' acceptance level towards technology helps to determine the issues in online learning and allow institutions as well as educators to explore possible solutions to ensure ODL can be implemented successfully and effectively.

\section{Methodology}

This study is descriptive and analytical. The primary data were obtained through questionnaires administered to the diploma and degree students from UiTM Melaka who studied in three different campuses which were UiTM Alor Gajah, UiTM Bandaraya Melaka as well as UiTM Jasin. Convenient sampling technique was used in this study and the survey was conducted online by using Google Form to obtain the responses.

The entire population for this study was 10,709 students that came from seven different faculties available in UiTM Melaka which included the Academic of Language Studies, Faculty of Art and Design, Faculty of Business and Management, Faculty of Computer Science and Mathematics, Faculty of Hotel and Tourism Management, Faculty of Communication and Media Studies and Faculty of Accountancy. The sample size for this study was 370 students that have been identified primarily by referring to the Krejcie and Morgan's table.

A five-point Likert-based scales were used to represent most suitable answer of the from the respondents. The description of the Likert scales used include, 1-Strongly Disagree, 2-Disagree, 3Neutral, 4-Agree and 5-Strongly Agree. To test the reliability of the answers of the questionnaires, reliability analysis is used in the study. The reliability analysis has been conducted by referring to the rule of thumb made by Perry, Charlotte, Isabella and Bob (2004). They described that Cronbach's alpha ( $\alpha$ ) 0.90 and above shows excellent reliability, 0.70 to 0.90 shows high reliability, 0.50 to 0.70 shows moderate reliability and 0.50 and below shows low reliability. A factor of independent variables (technology acceptance) and dependent variables (student understanding) have been tested using SPSS. 20.0.

The study used mean, standard deviation, correlation analysis to examine the relationship between technology acceptance with student understanding. Besides, the analyses also have been carried out to identify the most influential factors that give impact on student understanding during RMO in UiTM Melaka.

\section{Findings and Discussions \\ Descriptive Analysis}

Based on the findings of the study, it showed that from 370 questionnaires were distributed, all respondents successfully responded to the questionnaires. From the total number of respondents, 
INTERNATIONAL JOURNAL OF ACADEMIC RESEARCH IN BUSINESS AND SOCIAL SCIENCES Vol. 10, No. 9, 2020, E-ISSN: 2222-6990 @ 2020 HRMARS

majority of the respondents were female $(n=269,72.7 \%)$ and the rest were male $(n=101,27.3 \%)$. The highest majority of the respondent's age was between 18 to 22 years ( $n=307 ; 83 \%$ ), followed by 23 to 27 years $(n=61 ; 65 \%)$ and 28 to 32 years $(n=2,0.5 \%)$. Further, majority of the respondents were currently study in degree level $(n=241 ; 65.1 \%)$, while the rest were study in diploma level $(n=129$; 34.9). From all the respondents, majority were single $(n=368 ; 99.5 \%)$ and the rest of the respondents were married $(n=2,0.5 \%)$. The highest of respondents were from Faculty of Business and Management $(n=147 ; 39.7 \%)$, Faculty of Science and Mathematics $(n=110 ; 29.7 \%)$, Centre of Language ( $n=81 ; 21.9 \%)$, Faculty of Hotel and Management $(n=13 ; 3.5 \%)$, Faculty of Art and Design $(n=11 ; 3 \%)$, Faculty of Accounting $(n=5 ; 1.4 \%)$ and Faculty of Media and Communication ( $n=3 ; 0.8 \%)$. As an Overall, students from Kampus Bandaraya Melaka is the majority of the respondents $(n=163$; 44.1\%), followed by students from Kampus Jasin ( $n=114,30.8 \%)$ and Kampus Alor Gajah ( $n=93$; $25.1 \%)$. Hence, based on the frequency analysis of the overall demographic background of the respondents, it can be claimed that most of the respondents were from Faculty of Business and Management, were currently study at Kampus Bandaraya Melaka, female, aged between 18 to 22 years old, study in degree level and single.

\section{Reliability Analysis}

The internal consistency reliability analysis of all measurement items was measured through Cronbach alpha $(\alpha)$. In this study, the reliability analysis has been conducted by referring to the rule of thumb made by Perry, Charlotte, Isabella and Bob (2004) in which it indicated that Cronbach's Alpha $(\alpha) 0.90$ and above shows excellent reliability, 0.70 to 0.90 shows high reliability, 0.50 to 0.70 shows moderate reliability and 0.50 and below shows low reliability. Therefore, based on Table 1 , it revealed that all scales used in this study for both independent variable (technology acceptance) and dependent variable (student understanding) were valid and acceptable.

Table 1. Reliability Analysis Result

\begin{tabular}{|l|l|l|}
\hline NO. & CONSTRUCT & CRONBACH ALPHA VALUE \\
\hline 1. & Technology Acceptance (Independent Variable) & 0.514 \\
\hline 2. & Student Understanding (Dependent Variable) & 0.866 \\
\hline
\end{tabular}

\section{Correlation Analysis}

Table 2 shows the relationship between variable. In order to examine the relationship between technology acceptance and student understanding in this study, it had been interpreted by referring to the Strength of Correlation Interpretation guidelines by Salkind (2014). Based on the result, it signified that there is a positive and strong relationship existed between technology acceptance and student understanding $(r=0.613, p<0.01)$. The $p$ value that is lower than 0.01 represented that there is significant relationship between technology acceptance and student understanding. Therefore, the results implied that technology acceptance can positively influence student understanding about the content of learning activities that have been provided by their lecturer during ODL sessions. 
INTERNATIONAL JOURNAL OF ACADEMIC RESEARCH IN BUSINESS AND SOCIAL SCIENCES Vol. 10, No. 9, 2020, E-ISSN: 2222-6990 @ 2020 HRMARS

Table 2. Correlation Analysis Result

\begin{tabular}{|l|l|l|l|}
\hline & & $\begin{array}{l}\text { Technology } \\
\text { Acceptance }\end{array}$ & $\begin{array}{l}\text { Student } \\
\text { Understanding }\end{array}$ \\
\hline Technology & Pearson Correlation Sig. (2-tailed) N & 1 & $.613^{* *}$ \\
\cline { 3 - 4 } Acceptance & & .000 \\
\cline { 3 - 4 } & & 370 & 370 \\
\hline $\begin{array}{l}\text { Student } \\
\text { Understanding }\end{array}$ & Pearson Correlation Sig. (2-tailed) N & $.613^{* *}$ & 1 \\
\cline { 3 - 4 } & & .000 & 370 \\
\cline { 3 - 4 } & & 370 & 370 \\
\hline
\end{tabular}

**. Correlation is significant at the 0.01 level (2-tailed).

\section{Conclusion and Recommendations}

Overall, based on the result of the study, there is a strong significant relationship existed between technology acceptance $(r=0.613, p<0.01)$, and it can be concluded that technology acceptance become as a predictor in determining student understanding. Thus, the more students accept and understand how to use the technology, the more they could understand about the content of learning during ODL sessions. Technology become as an important tool and medium in Online Distance Learning (ODL) sessions since students could not go anywhere and most of them need to stay at home during the Restriction Movement Order (RMO) that have been enforced by the Government. Student need to depend on using online as an approach to get information and stay connected with learning activities provided by their lecturers.

Based on the findings, the researchers believed that the acceptance level of the student towards technology approaches that have been used and applied during the ODL sessions will be influenced by several factors. Moreover, some of the students possibly can accept online learning, yet, there are several barriers that restrict their involvement in online learning. According to Folorunse et. al (2006), low acceptance of online learning was due to the low awareness level, low computer literacy level, unreliable platform, and internet services. Likewise, obstacles faced by universities included infrastructure and students' limited access to computer (Iqbal \& Ahmad, 2010; Adah, 2012) which basically influence the technology acceptance among student that ultimately could affect their understanding during ODL sessions. It is undeniable that there are still students who do not have internet access or low connection at home, and even worse some of them do not have laptop or computer that becomes a crucial tool or equipment in online learning. Besides, prior research has found that lack of technical support leads to failure of technology adoption (Guimaraes, Gupta, \& Rainer, 1999). Preference for online learning is a vital dimension of online learning as it specifies that the user chooses the innovative system over more traditional approaches in learning course delivery (Tabak \& Nguyen, 2013). However, without users or student's acceptance towards technology, ODL sessions could not be done successfully.

Based on the findings, to ensure student can accept technology as a medium of learning, several recommendations have been proposed by the researchers. In open distance learning, it is very important for the students to initially have their own initiative and effort to regulate themselves to learn using technological tools and equipment. Self-regulation learning is referred to self-directed processes and beliefs in which students apply to monitor their academic performance (Tabak \& 
INTERNATIONAL JOURNAL OF ACADEMIC RESEARCH IN BUSINESS AND SOCIAL SCIENCES Vol. 10, No. 9, 2020, E-ISSN: 2222-6990 @ 2020 HRMARS

Nguyen, 2013). Research on student's self-regulatory strategies proved that such strategies are positively connected with course performance (Pintrich, 2000; Tsai, Tung, \& Laffey, 2008). The management of the university should understand that academic self-regulation has potential to affect academic success positively through enhanced focus and attention during instruction (Boekaerts \& Corno, 2005; Boekaerts, Pintrich, \& Zeidner, 2000; Williams \& Hellman, 2004). Therefore, the researchers suggested that the lecturers should help to encourage self-regulation learning among students and create this culture in ODL sessions. The lecturers or instructors play the important part in modifying their courses content and approaches so that improvements in selfregulated learning will be encouraged and fostered among students.

Most of the times, students perceive a technology as challenging and difficult to use because the software and hardware equipment that is essential to complete the tasks such as tutorial questions, individual and group assignment is not readily accessible. There is an evidence revealed that easy access to necessary equipment and technology is an antecedent of student acceptance of course management systems that conducted through online (Dos Santos \& Wright, 2001; Park, 2009). The management of the university or the lecturers need to ensure online learning system or technology applications such as i-Learn and Google Classroom outside of the university should be positively easy to use, thus increase probability of the study to accept the use of technology in learning activities. Furthermore, Internet accessibility should be the main focus in increasing student acceptance toward online learning. The management of the university as well as lecturers should come out with several efforts to ensure there is no students will be left behind during the ODL sessions. They need to identify the students who have problem in accessing the learning material and learning sessions and come out with the solutions to solve this matter such as using asynchronous (WhatsApp, Telegram or Google Classroom) instead of synchronous (Google Meet, Webex or Skype) interaction with the respective students.

The researchers also believed that students with good ability to use various tools and technologies will enable them to participate in online learning more easily. Besides, it is also vital for the students to have good technological background in order to be excellently involved in online learning, since they require to have some level of comfort while using the computer and web technologies (Lee \& Witta, 2001). Without good technological knowledge it becomes a hindrance for the students to take part in online learning. To increase acceptance level among the student towards ODL sessions, it is very crucial for the management of the university to take several initiatives to provide technology training to the students. Although, with the current pandemic situation, the technology training still can be conducted through online using several applications such as Google Meet, Skype, Webex and others. Training may be available through internal resources of institution, such as Information Technology department of a university. Correspondingly, training can be conducted outside of the university from software vendors or IT experts from other educational institutions. According to Agarwal and Prasad (1998), training whether conducted internally or externally, is positively related to technology acceptance.

For the future research, it is recommended that the researchers should broaden the population of the study to several other universities and not only focusing on one university, so that, the result of the study can be generalized. Finally, it is suggested that the future researchers should 
INTERNATIONAL JOURNAL OF ACADEMIC RESEARCH IN BUSINESS AND SOCIAL SCIENCES

Vol. 10, No. 9, 2020, E-ISSN: 2222-6990 @ 2020 HRMARS

investigate or examine several factors other than technology acceptance that perhaps could affect student understanding during ODL sessions.

\section{Corresponding Author}

Nurul Asma binti Mazlan

Universiti Teknologi MARA Cawangan Melaka Kampus Jasin, Jalan Lembah Kesang, 1/1-2, Kampung Seri Mendapat, 77300 Merlimau, Melaka

Email: asmamazlan@uitm.edu.my

\section{References}

Rahman, M. J. A., Yasin, M. H. M., Hamzah, M. I., Haron, Z., Daud, M. Y., \& Ensimau, N. K. (2020). Teaching and Learning-Assisted Learning Management System. Proceedings of the 3rd International Conference on Learning Innovation and Quality Education (ICLIQE 2019).

Agarwal, R., and Prasad, J. (1999). 'Are individual differences germane to the acceptance of new information technologies?', Decision Sciences, 30(2), 361-391.

Sabri, I. (2020). Perintah Kawalan Pergerakan. Berita Awani. Retrieved from 5 Mei 2020. https://www.astroawani.com/video-malaysia/infografik-perintah-kawalan-pergerakan-18mac-2020-31-mac-2020-1839802

Alebaikan, R., \& Troudi, S. (2010). Blended learning in Saudi universities: Challenges and Perspectives. ALT-J Research in Learning Technology, 18(1), 49-59.

Ngampornchai, A., \& Adams, J. (2016). Students' Acceptance and Readiness for e-Learning in Northeastern Thailand. International Journal of Educational Technology in Higher Education, 34: 1-10.

Arumugam, T. (2020). Covid-19: Education Sector grapple with Technology, Virtual, Online Classrooms. The News Straits Time. Retrieved from 5 Mei 2020. https://www.nst.com.my/news/nation/2020/04/585687/covid19-education-sector-grappletechnology-virtual-online-classrooms

Balabas E. (2017). Digital education in Russia begins with \#EdCrunch. Retrieved from 8 Mei 2020.

Bates, A. W. (1995). Technology, Open Learning and Distance Education. London: Routledge.

Boekaerts, M., \& Corno, L. (2005). Self-regulation in the classroom: A perspective on assessment and intervention. Applied Psychology, 54(2), 199-231.

Boekaerts, M., Pintrich, P. R., \& Zeidner, M. (Eds.). (2000). Handbook of self-regulation. Orlando, FL: Academic Press

Bosch, A. (1997): Interactive Radio for Instruction: TwentyThree Years of Improving Educational Quality, Educational Training Technology Notes Series 2, Washington, D.C., World Bank

Bradley, J., \& Yates, C. (Eds.). (2000): Basic Education at a Distance, World Review of Distance Education and Learning. London: RoutledgeFalmer

Dos Santos, B. L., \& Wright, A. L. (2001). Internet-supported management education. Information Services \& Use, 21(2), 53-64.

Edmunds, R., Thorpe, M., \& Conole, G. (2012). Student attitudes towards and use of ICT in course study, work and social activity: A technology acceptance model approach. British journal of educational technology, 43(1), 71-84. 
INTERNATIONAL JOURNAL OF ACADEMIC RESEARCH IN BUSINESS AND SOCIAL SCIENCES Vol. 10, No. 9, 2020, E-ISSN: 2222-6990 @ 2020 HRMARS

Gorka, R. E., Elizabeth, P. I., Argia, L. R. (2020). Teaching Minority Languages in Multiethnic and Multilingual Environments: Teachers' Perceptions of Students' Attitudes toward the Teaching of Basque in Compulsory Education. Journal of Education Science. 10(2): 25

Guimaraes, T., Gupta, Y. P., \& Rainer, R. K., Jr. (1999). Empirically Testing the Relationship between End-User Computing Problems and Information Center Success Factors. Decision Sciences, 30(2), 393-413.

Hartnett, M., St George, A., \& Dron, J. (2011). Examining Motivation In Online Distance Learning Environments: Complex, Multifaceted, And Situation-Dependent. International Review of Research in Open and Distributed Learning, 12(6), 20-38.

Hien, L., Veria, K., Piotr, K., Agata, M., Hirohito, I., Justyna, S., Jacek, B., Tanja, K. (2020). Internationally Lost Covid-19 Cases. Journal of Microbiology Immunology and Infection, 53, 454-458.

Keengwe, J., \& Kidd, T. T. (2010). Towards best practices in online learning and teaching in higher education. MERLOT Journal of Online Learning and Teaching, 6(2), 533-541.

Kireev, B., Zhundibayeva, A., \& Aktanova, A. (2019). Learning at Higher Education Institutions: Results of an Experiment. Journal of Social Studies Education Research, 10(3), 387-403.

Krejcie, R. V., and Morgan, D. W. (1970). Determining sample size for research activities. Educational and Psychological Measurement, 30(3): 607-610

Kurzman, P. A. (2013). The evolution of distance learning and online education. Journal of Teaching in Social Work, 33(4-5), 331-338.

Lee, C., \& Witta, L. (2001). Online Students' Perceived Self-Efficacy: Does It Change? Paper Presented At The National Convention of the Association for Educational Communications and Technology, Atlanta, GA.

Lee, S. J., Srinivasan, S., Trail, T., Lewis, D., \& Lopez, S. (2011). Examining The Relationship among Student Perception Of Support, Course Satisfaction, and Learning Outcomes In Online Learning. The Internet and Higher Education, 14(3), 158-163.

Rampal, L., \& Seng, L.B. (2020). Coronavirus Disease (COVID-19) Pandemic. Med J Malaysia, 75(2): $95-$ 97. 2 March 2020.

Zhou, L., Wu, S., Zhou, M., Li, F. (2019). 'School's Out, But Class' On', The Largest Online Education in the World Today: Taking China's Practical Exploration During The COVID-19 Epidemic Prevention and Control as an Example. Best Evid Chin Edu, 4(2): 501-519.

Mittelmeier, J., Rogaten, J., Long, D., Dalu, M., Gunter, A., Prinsloo, P. \& Rienties, B. (2019). Understanding the Early Adjustment Experiences of Undergraduate Distance Education Students in South Africa. International Review of Research in Open and Distributed Learning, 20(3), 19-38.

Moritz U. G. K., Yang, C. H., Gutierrez, B., Wu. C. H., Klein, B., Pigot, D. M. (2020). The effect of Human Mobility and Control Measures on the COVID-19 Epidemic in China. Science, 25 March 2020. Page 1-5.

Perry, R. H., Charlotte, B., Isabella, M., \& Bob, C. (2004). SPSS Explained. Routledge: London, UK

Pintrich, P. R. (2000). The role of goal orientation in self-regulated learning. In M. Boekaerts, P. R. Pintrich, \& M. Zeidner (Eds.), Handbook of self-regulation (pp. 451-502). San Diego, CA: Academic Press.

Luz, M. R. M. P., Rolando, L. G. R., Salvador, D. F., \& Souza, A. H. S. (2018). Characterization of the Reasons Why Brazilian Science Teachers Drop Out of Online Professional Development Courses. International Review of Research in Open and Distributed Learning, 19(5). 
INTERNATIONAL JOURNAL OF ACADEMIC RESEARCH IN BUSINESS AND SOCIAL SCIENCES

Vol. 10, No. 9, 2020, E-ISSN: 2222-6990 @ 2020 HRMARS

Saima, G., Joyshree, N., Shalabh, A., \& Asoke, N. (2012): Open and Distance Learning (ODL) Education System: Past, Present and Future - A Systematic Study of an Alternative Education System. Journal of Global Research in Computer Science, 3(4), 53-57

Salkind, N. J. (2014). Exploring Research. Edinburgh Gate: A Skill Building Approach, (4th ed.), New Delhi: John Wikey \& Sons.

Shachar, M., \& Newmann, Y. (2003). Differences between traditional and distance education academic performances: A meta-analytic approach. The International Review of Research in Open and Distributed Learning, 4(2), 1-20.

Tabak, F., Nguyen, N. T. (2013). Technology Acceptance and Performance in Online Learning Environments: Impact of Self-Regulation. MERLOT Journal of Online Learning and Teaching. 9 (1), 117-130.

Tsai, I. C., Tung, I. P., \& Laffey, J. (2008). Exploring how students' self-regulated learning influences the social nature of online learning. Paper presented at the 2008 Annual Meeting of the American Educational Research Association, New York, NY.

Urdan, T. A., \& Weggen, C. C. (2000). Corporate e-learning: Exploring a new frontier. WR Hambrecht Co.

Valentine, D. (2002). Distance learning: Promises, problems and possibilities. Online Journal of Distance Learning Administration, 5(3), 685-689.

Ventayen, R. J. M., Salcedo, R., \& Orlanda-Ventayen, C. (2020). Senior High School Students' Engagement and Readiness in eLearning Environment: Basis for a Proposed Online Learning Environment Model. International Journal of Scientific \& Technology Research. 9(2).

Viola, S., Saeki, E., \& Hendricker, E. (2019). Distance education in graduate training programs: Lessons learned from school psychology students. Journal of Educators Online, 16(2).

Willian, K., \& Chang, C. H. (2020). What Does 'Crisis' Education Look Like? International Research in Geographical and Environmental Education, 29(2): 107-111.

Williams, P. E., \& Hellman, C. M. (2004). Differences in self-regulation for online learning between first- and second-generation college students. Research in Higher Education, 45(1), 71-82.

William, K. K. (2018). Leapfrog Technologies: Can Mobile Technologies Competes Successfully with Traditional Learning Management Systems? Advances in Social Sciences Research Journal, 5(8): 234-250.

World Health Organization. (2020). Confirmed Covid Cases and Deaths in ASEAN: situation report, page 82.

Zhang, W., Wang, Y., Yang, L., Wang, C. (2020). Suspending Classes Without Stopping Learning: China's Education Emergency Management Policy in the COVID-19 Outbreak. Journal of Risk Financial and Management, 13(3): 55 